of information about the issue.

Today, the subcommittee's offices remain where they've been for decades-a high-ceilinged subterranean lair inside the Russell Senate Office Building. Unlike many offices on Capitol Hill, through which members shuffle as they jockey for more space, the place has a lived-in quality. Photos of Harry Truman and Joe McCarthy still adorn the walls, and staffers relish passing along talesincluding a few of questionable veracityabout the place's history.

"That desk over there-that was Bobby Kennedy's."

"The traditional happy-hour drink for our staffers is a Manhattan, since that was McCarthy's cocktail of choice."

I arrived at the subcommittee as a fellow with the American Political Science Association's Congressional Fellowship Program. My previous job had been as an investigative reporter for the Portland Press Herald in Maine, and I was attracted to the subcommittee in large part because of my professional background. But I quickly learned there are some important differences between the job of an investigative reporter and that of a Hill investigator. Congressional inquiries are very serious business, and as a result people are generally willing to cooperate. During my eight months with the subcommittee, I participated in many long meetings with representatives of firms whose business practices we were scrutinizing. Nonetheless, virtually all of these sessions were quite cordial. Folks politely accepted our requests for interviews, patiently answered our questions, and in many cases even arrived with detailed presentations. If I'd called the same people as an investigative reporter, I'd probably have gotten a curt "no comment."

Subpoena power was another part of the job that took some getting used to. On the surface, drafting a subpoena is similar to writing a Freedom of Information Act request, something I did many times as a journalist. I might dash off a Freedom of Information request in less than an hour, and I often sensed that government agencies spent just as little time responding to them. Writing subpoenas was different. I participated in the drafting of several, and I was struck by how much time and attention went into each one. It often takes a lot of resources to respond to a congressional subpoena, and the subcommittee does not issue them lightly. When they do, they try to strike the proper balance between ensuring they will receive enough information to conduct a thorough investigation and causing an undue burden to the recipient. Investigative journalists tend to act like bulls in a china shop, which is as it should be-they're outsiders whose job is to hold power to account. Congressional investigators, on the other hand, are insiders who have significant clout of their own. And from what I observed, they understand the need to use that power responsibly.

Finally, it took me some time to adjust to the comparatively slow pace and teamwork required by the subcommittee's investigations. As an investigative reporter, when I came across a promising lead, I had the opportunity to pick up the phone and pursue it. In Congress, I often wrote a memo and waited. This was sometimes frustrating, but it was obviously necessary. There's no room for freelancers in a congressional probe. There needs to be a single vision-and a central decision maker-especially in an investigation as potentially sprawling as our inquiry into the causes of the financial crisis.

When I arrived on the Hill in January, I hoped that I would still be on staff for at least the first hearing in the financial crisis investigation. That didn't happen. This article was written in August, at which point all the details of the subcommittee's work remained confidential, and a public hearing was still months away. Still, my eight months on Capitol Hill made for an enjoyable but unforeseeable ride. The Obama administration unveiled its proposal for financial regulatory reform. The U.S. economy began to show signs of life despite high unemployment and continuing problems in the credit markets. Congress established a bipartisan commission to explore the roots of the financial crisis-essentially a higher-profile panel asking the same questions as the subcommittee. All the while, the subcommittee methodically amassed a great deal of information about the causes of the meltdown. Financial reform was coming, and it was not too late to influence the outcome.

\title{
A Glimpse of History: Working for the House Majority Whip in the Early Days of the 111th Congress
}

\section{Bryan W. Marshall, Miami University}

\section{A FIRST DAY TO REMEMBER}

The rapidity, duration, and intensity of it all caught me by surprise. Nearly at a full run, I dashed through a corridor and down a winding staircase to my first morning meeting. I took a place along a wall with a few other staff, but my eyes were fixed

Bryan W. Marshall is an associate professor of political science at Miami University in Ohio. He was an APSA Congressional Fellow in 2008-09. upon the principals. Gathered around a vast table were the chairs, the majority leader, and my boss-the house majority whip. ${ }^{1}$ The discourse was mostly heavyPresident Obama's historic election, the burden of leadership, and the daunting task to balance politics and policy in order to deliver on the promises and hopes of the people who sent them. The immediate business was expanding children's health insurance and a stimulus package to turn around an economy teetering on the brink. The majority leader was resolute. Congress would need to deliver bold actions in order to overcome the deep anxiety of the times and to build confidence for the long struggle ahead. The whip was equally resolute as he summoned back hard lessons from lost eras-Roosevelt's New Deal and Truman's Fair Deal. Congress could not allow mistakes of the past to be repeated. With a clear appreciation of history, the whip 
made the case for a 21st Century New Deal that ensured the poor and most vulnerable would not be left behind. No sooner did I try to reflect upon this special moment and it was time to rush off once again.

This day would be full of meetingsall related to the economic picture and the development of the stimulus package. As incredible as my day had been, the last meeting proved to be even better than the rest. A senior staffer and I attended a one-on-one meeting between the whip and a member of the minority party. Without delving into details, I saw firsthand the whip's deep commitment to helping people. There was no partisan angst, just two members coming together in order to help communities in need. At the end of my first full day, I was somewhat unsettled having many more new questions than answers about Congress. Yet, I was still standing and taking in the fact that maybe this was how a great fellowship experience was supposed to be.

The Congressional Fellowship has given me a rare juxtaposition in perspective, one that I never thought I would have the opportunity to encounter. For years, I've been a simple watcher of Congress. I've peered from great distances trying to understand the complexity of its decisions and processes. Simply put, I've always been on the outside looking in. The fellowship provided a very different perspective, a look into the world of members from inside the Congress. Indeed, Richard Fenno demonstrated in Home Style and other works just how invaluable the soaking and poking method can be to understanding congressional politics. Given the magnitude of Fenno's influence on congressional scholarship, it's not going to surprise anyone to hear me say that Congress looks different up close than it does from afar. Thinking in the abstract or trying to quantify the decisions of members in empirical terms is one thing. But observing conditions in which members make decisions, or better yet-watching them make decisions-is quite another.

I've come to appreciate some of these kinds of distinctions in various contexts, such as with predicting or counting votes. The whip counts votes up close, while congressional scholars, more often than not, do so from afar. Of course it's fair to say that these are different professions with different goals, and so on. Still, predicting votes at 35,000 feet is a very different proposition than at two and a half feet. For legislative scholars, this sometimes may entail a variety of tools such as spatial models, cut points, or well-behaved utility functions. However from inside Congress, the whip approaches vote counting in a very different way. Here, the world revolves around building relationships and trust. The whip relies upon the whip count and a variety of related information to reduce uncertainty. There are certainly tradeoffs in all contexts, whether studying Congress from a distance or up close. I don't think one can ever replace the other. But the more we try to understand and appreciate such distinctions, the richer our overall perspective of Congress will be.

\section{SOAKING AND POKING IN THE CAPITOL}

The Capitol can be an incredibly busy environment, but even so, I've taken in some of the historical marvel of this place. So, let me begin by making a simple observation on the architectural beauty of my workplace.

\section{"Given the magnitude of Fenno's influence on con- gressional scholarship, it's not going to surprise anyone to hear me say that Con- gress looks different up close than it does from afar. Think- ing in the abstract or trying to quantify the decisions of members in empirical terms is one thing. But observing conditions in which mem- bers make decisions, or better yet-watching them make decisions -is quite another."}

On most mornings I would start the day by entering the Capitol from the House side, treating myself to the Hall of Columns, or by way of the tunnel coming up through the basement to the second floor where I often stopped at Christy's transformative rendering of the Signing of the United States Constitution. Tucked between statues of Father Junipero Serra (CA) and Joseph Wheeler (AL), there is a doorway leading to a large suite where I worked. The doorway is right off of Statuary Hall, and from there just a few dozen paces south is the House floor, and a few paces north is the majestic Rotunda. There are actually several suites on two main levels that comprise the Office of the Majority Whip and his staff. ${ }^{2}$ Most of the second-floor suite survived fires set by invading British troops and represents some of the oldest space in the Capitol. The suite is relatively unadorned but with high scalloped ceilings and massive windows that provide stunning views of the National Mall. There are two fireplaces, one just a few feet away from my desk, where it is said that Representative Lincoln (1847-49) often sat to pen letters. The space previously served as a private lobby for members, a document room, and post office of the House. Winding up a staircase (in the east corner) there is an entrance to the old public and ladies' galleries overlooking Statuary Hall. On occasion, this area served as a great perch to watch special events such as when some friends and I spied on the media gaggle covering President Obama's first address to Congress.

APSA's orientation program provided my class of incoming fellows with practical advice and a useful set of expectations of what it would be like as Hill staffers. One of the most useful pieces of advice was to attach yourself to the most experienced staffer you could find because you will likely learn more from that person than anyone else. As it happened, good fortune was on my side because the whip's office is stacked with a very deep bench of talented, professional, and dedicated staff. Even more impressive, the staff maintains their poise in the most difficult of circumstances-usually working under incredibly tight time constraints to tap down daily and sometimes hourly crises. With a 256-member caucus and the array of priorities they represent, there's always an issue somewhere that the leadership staff must deal with. Like most positions, trust is earned. But once I did, their world became part of my world and I was treated as a valued member of the team. Because the staff was willing to share their world with me, I could for the first time see Congress-in all its marvelous complexity-from the inside. Although I didn't realize it at the time of orientation, APSA's advice would be prescient. I was able to watch, listen, and learn from some of the Hill's very best.

The whip's office was a near-perfect vantage point to study party leadership and learn how leaders interact with several factions and the rank and file of the caucus more broadly. There are whip, caucus, and a variety of other types of meetings where I could learn what issues were important to individual(s) and group(s) on any particular piece of legislation. I also spent considerable time following legislation through the legislative process. I would sometimes attend committee hearings and markups to learn about issues and/or potential conflicts that could 
be useful to the leadership. The Rules Committee and leadership-staff meetings were especially insightful for understanding the application of political strategy to legislative procedures. From these multiple venues, one is provided with a fairly comprehensive feel of the substantive and political issues raised on legislation. With this information in hand, the leadership can effectively work to build coalitions and reduce uncertainty on the floor.

In addition, working for the whip allowed me to meet and listen to an incredible variety of interesting people. Listening, or rather, careful listening is an underappreciated skill outside the Hill. Listening is much more than hearing and remembering what someone said. But careful listening also involves asking thoughtful questions and understanding "asks." I would sometimes attend staff meetings with constituent groups, national associations, business and social groups, and public organizations of all different sizes and stripes. These opportunities were often very useful for sharing perspectives, communicating, and educating those involved about the issues of concern or accomplishments of the group in particular areas of public policy. There were also ambassadors, heads of state, parliamentary leaders, cabinet secretaries, political strategists, and many others. The stream of native South Carolinian, nation$\mathrm{al}$, and international visitors represented an absolutely fascinating sample of people. ${ }^{3}$

One of my favorite places and where I spent a great deal of time was the House floor. Here, I was able to watch members as they voted on most of the major pieces of legislation that hit the floor. I probably learned more on the floor about individual members and how they interact with each other than any other place. Members tend to have a camaraderie about them on the floor. When you're on the floor, you can see that there are many friendships and as you watch the whip or other leaders work the floor you appreciate how important relationships can be. In addition, one can experience a full spectrum of emotions on the floor, from the celebration of a major legislative victory to the quiet sorrow when sharing a moment of silence to remember tragedy. There was a feeling of history making on the floor with the passage of President Obama's first budget resolution. There were also some very exciting votes. For example, the passage of the war supplemental and the energy/climate change bills, which were probably the most exciting. These were real nail-biters and characterized by considerable uncertainty on the floor. Then, there was the record-setting day of votes on the Commerce, Justice, Science Appropriations bill. On this bill, the minority party availed every parliamentary tactic to make a marathon day of floor votes. In fact on a motion to reconsider, a large number of the minority rank and file lined up to individually change their votes via paper ballot. ${ }^{4}$ At the end of the legislative week, the majority leader and usually the minority whip conduct the leadership colloquium. The eloquent colloquiums provide insight not only on the upcoming week's agenda, but also signal some of the major arguments the leadership may use in the messaging struggle that follows to shape public opinion.

A FEW OBSERVATIONS ON LEADERSHIP STYLE AND THE ROLE OF THE MAJORITY WHIP

It is too early to know with certainty how history will view the 111th Congress. But with its early legislative accomplishments and current pace, it will likely be judged as one of the most successful in recent history.. The 111th Congress has already enacted a number of major policy initiatives such as the economic stimulus package, credit card and Pentagon acquisition reforms, sweeping tobacco regulations, expansion of national service programs, a war supplemental, and President Obama's first budget resolution to name a few. In addition to these, the House has passed several major bills such as a national energy policy, defense authorization, PAYGO, and the 12 appropriations bills-all before the August recess.

The impressive legislative record of the 111th Congress is attributable in no small measure to enlarged Democratic majorities in both chambers and a charismatic young president with a popular agenda. However, one of the biggest reasons for Congress's success has been the Democratic leadership in Congress, and in particular, the extraordinary role of the majority whip-Jim Clyburn. The whip's rising star as a legislative leader began when he was first elected to Congress and chosen by his peers to be president of his freshman class (1994). From there, his leadership role grew serving as chair of the Congressional Black Caucus (1999-2001), vice chair and chair of the Democratic Caucus (2003-06) and (2006) respectively, and elected to his current position as House majority whip in 2007 (Behre 2007). ${ }^{6}$

Whips have taken on different styles. Tom DeLay (R-TX) was known as "the Hammer" because of his approach toward enforcing the party line. My boss uses a very different approach. He has a softer and gentler style, preferring the velvet glove over the iron fist. The majority whip has been described as a gracious Southern representative (Evans and Grandy 2008, 192). He is deeply respected and trusted by the seven distinct factions of the Democratic caucus (Rogers 2008). He is viewed as a team player who uses power wisely and fairly. So, he has a unique ability to pull disparate groups in the caucus together. I think the structure of the whip organization reflects the importance he places on reaching out and building relationships with all members of the party caucus. Indeed, the whip has created a whip organization that seeks to give voice to the rank and file (Brush 2007). Whip and senior whip meetings, hearing sessions, and other caucus gatherings keep the whip aware of rank-and-file concerns. The open flow of communication to the whip ensures that members can fulfill their representative duties and it strengthens institutional ties. Thus, the whip's style and organization helps explain how he effectively fulfils his role as whip.

Although Speaker Pelosi and Leader Hoyer are somewhat more visible in their roles as the public face of the party, the whip's behind-the-scenes responsibility is no less important. Among other important duties, the whip tallies voting intentions on party priorities and persuades wavering members to ensure sufficient floor support of the party's position. Securing the votes is fundamental to achieving the party's policy and electoral fortunes. But the whip's role entails much more than putting the policy question to the caucus and delivering a winning majority. The whip also has to balance competing interests within the party. In terms of the scholarly literature, the whip's overall role is critical to coordinating collective action of the party in the production of public goods (Smith 2007; Evans and Grandy 2008, 209-12). In terms of collective action, the whip (and leadership more generally) try to ensure that members of the caucus contribute to the party's goals. There has to be a sense of fairness and equity in how the party distributes the benefits of collective action and the pain (or cost) of such action. This is all the more difficult because any given policy creates a new profile of member interests that may require a different distribution of costs and benefits to achieve the party's goals. If one group or faction feels wronged over another, the leadership risks a revolt. I'll end this point with an apt saying from a member that I think captures this dynamic (and 
I paraphrase), "you quit loading the wagon when the mules are fixin to quit pullin."

\section{CONCLUSION}

Through theory and tools, scholars have built an extraordinary view of the Congress. Until now, I've had a bird's eye view of Congress. The Congressional Fellowship has provided a wonderful complement to such a view. There's no substitute for learning about congressional politics as a participant-observer. Indeed, the fellowship has given me the opportunity to experience Congress-to see members in their world. But the fellowship experience affected me in an unexpected way as well. Ever since that first day, I began to appreciate better some of the constraints members face, and have become more invested and hopeful in Congress.

\section{REF ER E N C E S}

Behre, Robert. 2007. "Mr. Clout." The Post and Courier, February 18, A1.
Brush, Silla. 2007. "Hidden Power on the Hill." U.S. News and World Report, March 15, 42-43.

Evans, C. Lawrence, and Claire E. Grandy. 2008. "The Whip Systems of Congress." In Congress Reconsidered, 9 th ed., ed. Lawrence C. Dodd and Bruce I. Oppenheimer. Washington, D.C.: CQ Press, 189-215

Fenno, Richard Jr. 1978. Home Style: House Members in Their Districts. New York: Harper Collins Publishers.

Rogers, David. 2008. "Clyburn Herds a Diverse Flock". Politico, June 19, 1-2.

Smith, Steven S. 2007. Party Influence in Congress. New York: Cambridge University Press.

\section{NOTES}

First and foremost, I want to thank my beautiful wife, Candace. Without her support and active encouragement, this wonderful experience would not have been possible. Moreover, if the richness of an experience can be gauged by the friendships one makes, than I've been truly fortunate with my time on the Hill. I'm greatly indebted to colleagues from Miami University, APSA, Congressman Clyburn, and my many friends in the whip's office and other offices on Capitol Hill. To all of you, thank you.

1 The Honorable James E. Clyburn is the House majority whip and represents South Carolina's
Sixth District.

2 The offices in the upper suites are beautifulsome with original painted mural ceilings and other detailed adornments that deserve greater description than I dare try here.

3 I don't dwell on constituency-representative relations in this article for the sake of brevity. But I will say that the whip and members more generally stay closely attuned with the constituents in their districts.

4 The clerk calls out each name and the respective vote change on the floor.

5 Indeed, the legislative productivity of the 111th Congress will likely compare well with some of the more important markers like Speaker Wright's 1ooth and Speaker Gingrich's 104th .

6 Congressman Clyburn's leadership role actually started rather early as he was elected president of his NAACP youth chapter at the age of 12 (http://clyburn.house.gov/clyburn-biography).

\title{
External Reviewers; Friends or Foes? Political Science Panel Embraces Reviewers!
}

\author{
Graham Wilson, Boston University
}

Tf $\mathrm{f}$ it is time for an external review-or if the dean announces you are having one anyway-it almost certain that your first reaction as a department chair will be that this is bad news and that the red coats are coming! After all, at very least an external review is going to result in a considerable amount of extra work. And the review can be a moment of what a panel member who had served as a dean termed a time of "extreme danger"; a bad review can really damage a departments standing and prospects with the dean and university administration more generally. However at the 2009 Annual Meeting a distinguished group of political scientists (Evelyn Huber, Stephen Majeski, John Woolley, Michael Kraft, and Gretchen Bauer) chaired by

Graham Wilson is a professor of political science and director of graduate studies at Boston University. He is the chair of APSA's Committee on Departmental Services.
Graham Wilson of the APSA Departmental Service Committee urged chairs to be positive. Having been on both the receiving and giving sides of the review process, panel members uniformly concluded that it can be a very positive experience for departments and their chairs.

Panel members recalled how they had seen external reviews prompt departments into making crucial decisions-in one case transforming a previously mediocre graduate program, and in another case confronting a difficult choice they had long avoided. The process of preparing for the review will prompt a department to think more seriously about its curriculum, its governance, and its priorities than it would otherwise. As one panelist argued, most departments get used to their established curriculum and ways of doing things even though there may be room for improvement: "There isn't a department that couldn't better than it is right now." External reviews can help a department chair advance a reform agenda. One former department chair thought that an external review had helped him advance his goals for reform and improvement in the department far beyond what he could have achieved had it been just the chair arguing for the department. Sometimes reviewers can be problem solvers, for example, seeing ways to help departments achieve their goals with what they had thought to be inadequate resources. One panelist had served on a review team that had seen a restructuring graduate program make what seemed like inadequate and unchangeable funding for graduate students stretch much further. And even though external reviewers are often told that it is pointless for them to ask for more resources for the department they are reviewing, their report can be the basis over the medium and long term on which a department can request them. A review that argues that the department is too weak in a major subfield to be fully successful makes a case 